Colloquia Litteraria

UKSW

$4 / 2017$

PIOTR CHLEBOWSKI

\title{
DEATH IN FORUM BOARIUM; SOME REMARKS ON CANTO XXIV OF NORWID'S QUIDAM
}

For Professor Stefan Sawicki with gratitude

Canto XXIV should be considered the central part of Norwid's long poem Quidam. It is also a parable. Quidam is an epic picture of Rome in the times of the Emperor Hadrian and the birth and 'maturing' of Christianity. This canto, as we remember, the death scene of the protagonist, the son of Alexander from Epirus, who, as Norwid wrote in his introductory commentary, was "killed [...] almost by accident, and in a carnage!" (III, 79). ${ }^{1}$ In the poem "Do Walentego Pomiana Z.” (“To Walenty Pomian Z.”), in which Norwid once again 'explained' the sense and summarized Quidam, he recalled this crucial event and added:

- I, jakby nie czas już był na miłość, mój młodzian

Wywróconego kosza kwiatami przyodzian,

P r z y p a k i e m więc pogrzebion, jak zabit pr z y p a d k i e m $\mathrm{W}$ miejscu, gdzie go sprzeczności zawiodły p r z y p a d k i,

Prawdy nie znając (lubo może jej był świadkiem),

Bohater! a za pole bitw cóż znalazł?... jatki! $(\text { II, 155) })^{2}$

\footnotetext{
1 Quotations from Norwid's works: Cyprian Norwid, Pisma wszystkie, ed. by Juliusz Wiktor Gomulicki, v. I-XI, Warszawa 1971-1976.

2 And, as if it was no longer time for love, my youth/Garlanded with flowers from the overturned basked/B y a c c I d e $\mathrm{n}$ t buried, as he was killed b y a c c I d e $\mathrm{n} t /$ In the place to which he was driven by contrary a c c I d e $\mathrm{n} t \mathrm{~s}$./Not knowing
} 
It could be said that Norwid consistently drove his text in the direction of this event. Everything that takes place later, the 'Shakespearian sequence of events' which gets into motion: the deaths of Sophie, Arthemidor, Jason the Magus, news of the disaster of Barchob-these are all results of this 'accidental' death of the main protagonist. It is obvious that this is not a direct, cause-and-effect result, but it is deeply rooted in the laws and mechanisms of changes which are civilizational and cultural, but mostly of ethical and which are preserved in verses of poetry.

Let us now concentrate on the key issue: the scene of the protagonist's death. It takes place in one of Rome's squares. The description of this place strengthens the dramatic tension and its situational realism. It also stresses the ironic resonance of this event, its 'accidental' character, which paradoxically converges and opens the perspective of the Resurrection (the key event in the New Testament). At the same time this is a picture worthy of such contemporaries of Norwid as Flaubert and Balzac:

Było to bowiem miejsce P la c e m zwane

Przedajny m - gwarne, wilgotne, zaulne

W upały nawet, że nie zamietane,

Temperaturę mające szczególny

I coś szarego w powietrzu jak pyły.

Tu, tam, wnętrzności leżały na bruku,

Indziej się kwiatów wieńce czerwieniły -

Ptasząt śpiew wmięszan do powózek huku,

A do cięć głuchych w mięso ludzka mowa,

Dawały temu obrazowi c ało ść

(III, 209) $)^{3}$

the truth (although he may have witnessed it)/A hero, and what did he find for a battlefield-butchery.

3 It was the place called the Market/Square: busy, damp cul-de-sac./Not cleaned even during heatwaves,/with a specific temperature/And something grey, like dust, in the air./Here and there guts were scattered on cobblestones,/Elsewhere wreaths of flowers were reddening -/Birds' songs mingled with the noise of carts,/And deaf cuts with human speech,/Gave wholeness to this picture. 
Gomulicki correctly deciphered the name which Norwid used "Plac Przedajny"- "Market Square": "Great market square on the Tiber (on its left bank) called Forum Boarium (Cattle Market), because it was used mostly for trading cattle. There were also several temples in this square, among others, the temple of Portunus, the patron of ports and storehouses. ${ }^{4}$ To be more exact, it is worth adding that in Norwid's times this temple of Portunus was regarded as the temple of Fortuna Virilis.

This was-particularly in the times of the Republic-a very important place in Rome. The Forum was located on the plain stretching between three hills: Capitoline Hill, Palatine Hill and Aventine Hill. It was here that Italy's two main routes crossed: the Tiber River and the land road connecting Etruria with Campania (northsouth). It was here that the first wooden bridge-Pons Sublicus-was built in the seventh century B.C. Close to the Forum there was Portus Tiberinus, the trading port. The phrase "miejsce zaulne" ("a cul-desac") which Norwid used, according to the footnote, should be treated metaphorically. This is not a real 'cul-de-sac' which Norwid had in mind, but a place which is 'precarious', a place of dubious reputation, located away from the mainstream of life. In the times of the first Empire Forum Boarium was losing its importance, receding slowly from the symbolic 'centre' of Rome.

\footnotetext{
4 J. W. Gomulicki, Objaśnienia, in C. Norwid, Pisma wybrane, vol. 2: Poematy, Warszawa 1985, 429.

5 On the role of Forum Boarium for Rome in the early period see Anna Sadurska. Eadem, Archeologia starożytnego Rzymu, vol. 1: Od epoki królów do schyłku republiki, Warszawa 1975, 41, 43. See also S. B. Planter, Th. Ashby, A Topographical Dictionary of Ancient Rome, Oxford 1929,. 224 and G. Lugli, Itinerario di Roma antica, Milano 1970, 303-328; E. Nash, Bieldllexikon zur Topographie des antiken Roms, v. 1, Tubingen 1962. An important source on Forum Boarium is Lyngby, Beitrage zur Topographie des Forum-Boarium-Gebietes in Rome, Lund 1954, See also. C. Anderson, The Historical Topography of the Imperial Fora, Bruxelles 1984. M. Cary, H. H. Scullard, Dzieje Rzymu. Od czasów najdawniejszych do Konstantyna, trans. By . J. Schwakopf, v. 1, Warszawa 1992, . 86 and next.
} 
As one researcher has correctly noted: "Quidam anticipates the coming of the tenth Muse" (which suddenly appeared in a few verses of a letter to Józef Komierowski from 6 September 1853). As in a film script the very description of the situation unleashes the drama, while the apparently static scenes are governed by the rule of montage and parallel plots, thanks to which events can be discretely commented upon, and add dynamism to the story line. Everything is happening in real, defined space and in real, defined time. As in a carefully composed frame, everything matters, all objects and gestures, appointed by very meticulous directions. ${ }^{6}$

The concentration on gestures and objects, leaning towards its exquisite analysis, gives the surrounding reality metaphorical, or even symbolic, meanings. Almost every detail is enriched by an additional motivation, which refers the depicted world to the sphere of sacrum. In the general plan of the history of the world, the history of Rome reveals an apparently invisible face: of 'holy history'. Different details of the depicted world acquire some internal semantic depths, which can be reached only if they are properly recognized and placed in the real world. Similar procedures are used in films, particularly the ones of such film directors who treat the surrounding world as a sign of the 'invisible'-most often they deal with anthropological issues from the semiotic point of view. This is, for example, the case in the films of Bertolucci, where the landscape and each of its elements individually acquire their metaphysical, and maybe, sacred sense; also, in the 'chamber' films by Kieślowski, the phenomenological closeness and unusual contemplative perception of objects and men lead to metaphysical qualities and values. We deal with a similar procedure in Quidam, where the description of reality (leaning towards realism, and even, at times, towards poetic 'verism') has similar functions.

In this scene we are focusing upon the place, people, gestures, even smells-they take on additional motivation. Everything, frame after

\footnotetext{
6 E. Kiślak, Cień arcydzieła, in v. 1: Trzynaście arcydzieł romantycznych, ed. by E. Kiślak, M. Gumkowski, Warszawa 1996, 206.
} 
frame, as if in slow motion-so as not to lose even a tiniest moment of the events-undergoes the process of becoming metaphorical and symbolic:

Barchob, od kupca odwróciwszy lice, Napotkał oczy przechodnia ku niemu Zwrócone, jako letnie błyskawice, Lecz te wraz gestem pytającym: „Czemu?” Usunął, sprawę swą kończąc z rzeźnikiem.

- Dziewczyna jakaś przeszła między niemi, Naczynie niosąc bełtające mlekiem Jak łani, ledwo że tykając ziemi.

Ta zawołała: „Q u i d a m ? ” - za człowiekiem, Który szedł, koszem do pół osłonięty, A ziół i kwiecia woń powiała wkoło Ostra, jakoby woń koszonej mięty; Syn Aleksandra schmurzył blade czoło, Nie mogąc pojąć milczenia Barchoba, I szukał okiem, zali się nie myli?

- Gdy ruch się zrobił w tłumie - tak że oba, Za tłumem, w jedną stronę się zwrócili.

The word "quidam" spoken by a passing girl receives the status of a name, and is motivated by a similar situation in a different place-in canto XII when-as we remember- "the word 'quidam' started havoc"(III, 134). But other elements present in the quoted fragment also find similar justification. Some of the details refer

7 Barchob, having turned away from the trader/Met the gaze of a passer-by turned/ On him, like summer lightening,/but them together with a questioning gesture "Why?"/He removed, ending his business with the butcher./-A girl walked between them/With a vessel of milk/As a hind barely touching the ground./She called "Quidam?"- after the man,/who walked half hidden by a basket./Scent of herbs and flowers spread around/Sharp as if the scent of mowed mint./Alexander's son's pale face went gloomy./He couldn't understand Barchob's silence,/And searched with his eyes, was he right?/When the movement started in the crowd - so that both of them/Followed their eyes after the crowd. 
us to the realities of the city. It is worth noting a man carrying a basket with herbs and flowers, and the "scent of mowed mint". This is a motive which keeps returning, and thus acquires the valour of importance. After all, it starts a rich cycle of metaphors: both in ancient religions and in Christianity herbs and flowers were signs of the spring, harbingers of re-awakening life, hope for future fruits. They were used to decorate temples, statues of gods, sacrificial animals. Flowers, particularly in the beginnings of Christianity, were a symbol of the sacrament of marriage, as well as baptism. That is probably why they are connected with the protagonist. A heap of flowers he throws himself into in Canto XX is a harbinger both of death and, maybe, an unconscious baptism of fire (approximating the perspective of the Passion), which the son of Alexander will face in the Market Square:

I wstał - kosz wziął w ręce,

Na łoże sypnął nim, z ową pustotą

Niezgrabną, którą gesta niemowlęce

Psują rzecz, cale nie troszcząc się o to -

Lampa u schyłku promień niosła drżący -

On legł na kwiatów stos, jak człowiek śpiący.

$$
\text { (III, 193)8 }
$$

And, for comparison, let us quote a short fragment where the motive of flowers appears after the death of the protagonist:

Młodzieńca cichy trup leżał, okryty

Kwiatami z koszów gwałtem wywróconych -

$$
(\text { III, 213 })^{9}
$$

\footnotetext{
8 And he got up and took the basket in his hands,/Sprinkled it over the bed with emptiness/Clumsy, which baby's gestures/spoil things, not caring at all -/The almost extinguished lamp had flickering light/He fell on the heap of flowers -/As a sleeping man.

9 The young man's corpse lay covered/With flowers by violence overturned.
} 
How important the scent of mowed mint is in this fragment! First of all, it makes the scene more realistic, but at the same time it reveals, in the context of subsequent events, its metaphorical value. It is tempting to deduce which particular species of this plant we are concerned with here: This is probably not Mentha pipertia (pepper mint), the most popular these days on our continent which as a spontaneous crossbreed appeared only in the eighteenth century in the English county of Surrey. ${ }^{10}$ In Antiquity there were many species and subspecies of mint, for example Mentha tomentosa, Mehtna aquatica or Mentha rotundifolia. In the Mediterranean region it was long-leaved mint Mentha longifolia which was particularly highly valued for its strong scent and taste; for example Jews used it not only as a spice, but also as an air refresher (it was thrown on floors in synagogues). However, in this case the layer of symbolic meanings is more important than botanical accuracy. Let us note that it is not so much the mint itself which matters here but "the scent of herbs and flowers", which with its intensive sharpness is "as if the scent of mowed mint". This tiny expression "as if" forces us to abandon botanical hobbies and directs our attention to metaphorical senses. Because although the realistic layer-as a result of the fact that in Quidam we have frequent use of the technique limiting the narrator's omniscience-is strongly reduced, the metaphorical one is very active. Mint which appears in this way (mostly the scent of it) directs our sensitivity to ancient mythology and culture. The very word "mint"-'mentha' in Latincomes from the Roman goddess Mentha, who personifies the human mind, intellectual prowess, wisdom. Mint, according to Pliny, was to stimulate the human mind, and that is probably why Roman students of philosophy wore wreaths of fresh mint. So, if we recollect now what is the motivation of the young Epirian in Rome, why he has come to the centre of the Empire, and what is the sense of his initiatory

\footnotetext{
${ }^{10}$ It is from this area that the first description of this plant comes. See: J. Ray, Synopsis Methodica Stirpium Braitannicarum Tum Indigenis in Agris Cultis Locis Fuis Despositis Additis Generum Characteristicis Spe-ciarum Descriptionibus et Vivium Epitome, Editio Tertia, Londini 1724, table 10, figure 2, 234.
} 
wandering from the Grammarian to Artemidor, from Artemidor to the Magus, the meanings associated with mint discussed will be fully justified. Let us not forget, however, that the Epirian will be in a short moment killed by an axe. The scent of mint (mowed mint) foretells death. Here, we should again refer to ancient myths and legends. According to one of them, quoted by Ovid and Strabon, ${ }^{11}$ Minte, a young nymph from the Underworld, was transformed into a small plant with an intense scent by Hades, who wanted in this way to protect his lover from the persecutions of the jealous Persephone. Therefore, mint, through this myth, was connected with the Underworld, the world of the dead, even with death itself. In light of the 'accidental' torment and death of the young Epirian, and also of its exegesis performed by the Gardener, it is possible that Norwid also here set in motion symbolic senses connected with Christianity. Mint is called the herb of Holy Mary (Herba Sanctae Mariae) or the 'holy herb'. According to an old custom, if one found some mint in a field, one had to grind it instantly with one's fingers and smell it, because, as the saying from Abruzzia goes: "If you find mint and don't smell it, Christ will not appear at your death".12

The motif of mint acquires it symbolic and metaphorical importance in Quidam thanks to the realistic motivation: there is no detail, event or gesture which is removed from reality, from concrete time and space. It can be claimed that Norwid did a thorough, almost archaeological job, to ground the plan of events in historical and topographical realities. This method-as Irena Sławińska once remarked-was an important element of Norwid's craft. ${ }^{13}$ The recalled motif of the flowers and herbs which a man carries "half hidden

11 See Owidiusz, Metamorfozy X 729 and Strabo, Geografia vol. VIII (for example, H. L. Jones, J. R. S. Sterrett, London-New York 1932, 344.

12 B. Szczepanowicz, Atlas roślin biblijnych. Pochodzenie, miejsce w Biblii i symbolika, Kraków 2004, 173.

13 Although Sławińska was discussing narrative prose, but her findings may be extended to the whole oeuvre of Norwid. See, Eadem, O prozie epickiej Norwida. $Z$ zagadnień warsztat upoety-dramaturga, in Eadem, Reżyserska ręka Norwida, Kraków 1971, 277-320. 
by a basket" also has its (topographical) justification. Not far from Forum Boarium (now it is Piazza Bocca della Verita), where the scene of the Epirian's death unfolds, there was Forum Holitorium (now it is San Nicola in Carcere), a large square which in ancient times was used as a fruit and vegetable market. It was a large area between Capitoline Hill and the Tiber. Therefore, Forum Boarium and Forum Holitorum were located in the immediate vicinity. ${ }^{14}$ Most probably it was from there or in this direction (it is difficult to define unambiguously in the text) that the man with a basket of flowers and herbs was going.

There are some more issues indispensable for the understanding of Canto XXIV: the motif of the bull and the time of events suggested by Norwid-the time in which Alexander's son dies. Let us recall the first of these motives as it is presented in the text:

W głębi zaś placu powstała rąk chmura:

Lud na bezsprzężne powskakiwał bigi, „Wół! w ó ł! - wołając - ś w i ę t y !” - przy tym: „H u r r a !” A podbiegając $\mathrm{z}$ krzykiem na wyścigi, Kapłańskie sługi, w podkasanych szatach, Z stryczkami w ręku sunęli po kwiatach, Po koszach, w błoto ległych z owocami. Kapłańskie sługi biegli ze stryczkami, Gdy wśród zwichrzenia tłumu rogi złote Byka, co onę rozganiał hołotę, Jakoby księżyc zaledwo wschodzący $\mathrm{Na}$ ziemię zleciał, toki nierównemi Siekły przez obłok ludu pierzchający, Od ziemi w górę i z góry do ziemi. Policja rzymska w tę wmięszana sprawę Organizować poczęła wyprawę, Głosząc: "Schwytany ma być! jest schwytany!”Włóczniami tłumy cofając do ściany.

I wraz porządek gwałtem rósł, gdy szpiegi

Skoczyli niemniej szykować szeregi -

Czas, w którym człowiek z toporem na ręku

14 See G. Lugli, Itinerario di Roma antica, 282-303. 
Uderzył w ramię młodzieńca z Epiru -

Szukającego w gwarze tym współ-jęku.

- Tknięcie to, wzgardy pełne, twarz nieznana

Męża z toporem onym - tak dobodły

Poniewieraną wrażliwość młodziana,

İ̇ ściągnął k’niemu leniwą prawicę,

Leniwą wargą drgnął i wyrzekł: „P o d ł y ! ” -

Ale już wtedy, gdy go jak kotwicę

Zgiętego rzucił o ziemię.

„Prze-bogi!! -

Tłum zaczął wołać - morderst wo Kapłana! ” -

Zwłaszcza iż wołu właśnie złote rogi

Ujęto stryczkiem, a rzesza wezbrana

Nie miała ujścia chuciom ani drogi.

Policja z swymi skoczyła włóczniami,

Gdzie Aleksandra syn trzymał pod nogą

Męża - ajakiś ogrodnik słowami

Łagodził rzeszę pachołków złowrogą,

Co krwawe stryczki nosi i kadzenia,

Ilekroć żertwa jest gdzie do spalenia.

„P u s z c z a j!” - zawoła setnik, gdy młodzieniec:

„Niech zaraz rzuca topór!”-k'czemu zasię

Ogrodnik dodał: „Ztoporem szaleniec!” -

A setnik ręką skinął - w tymże czasie

Kapłański sługa wyrwał się - a potem

Brązowy topór jak ptak z rąk mu sunął,

Powietrze skrzydłem swem przekroił złotem -

Padł - Aleksandra syn zadrżał i - runął.

$$
(\text { III, 210-211) })^{15}
$$

15 In the back of the square many hands appeared/Folks jumped onto carts,/ Shouting: 'bullock, bullock', and 'the holy' and 'hurrah!'/While running and shouting/Priests' servants with tunics tucked up,/With ropes in hands were running over flowers/Over baskets lying in mud with fruits/Priests' servants were running with ropes./When among the tumult of the crowd the golden horns/Of the bull which was chasing the populace/As if the very new moon/Fell into the ground, so they unevenly/Cut through the escaping cloud of people,/Up and down, Down and up./Roman police got involved in it/Started to organize an expedition,/Saying: "It 
The text dramatizes the present moment-the moment of the death of the main protagonist. An accidental scramble connected with the escape of the bull ends tragically for the Epirian. And it is here that the scenes undergo this unusual framing, and the changes of these 'picture-frames' is here much faster and much more fluid than in the scene of the nudging of Barchob. Here also, many elements almost directly bring questions about the sense, meanings, and their role in real and metaphorical space. Why do we have a "bull" at times, and a "bullock" at other times? Who are these "spies" who jumped to "get ready"? What were they doing in the Market Square? Does the moon, appearing in the secondary imagery (as a simile) have its symbolic meaning in the text, or is it just a risky rhetorical figure? This is, of course, not a complete list of questions. Such a list could be made much longer. However, the key doubt and uncertainty in the case of this dramatic scene is connected with the bull and its catcherspriests. How did priests happen to be in the Market Square-Forum Boarium? Why did they try to tame the bull (called "a holy bullock" by the crowd), which probably tried to get free? Why does the bull in this scene have golden horns? In the second and third editions

must be caught! Is caught!-/Backing the crowds to the wall./And quickly order came, when spies/Jumped to get ready./Time when a man with an axe in his hands/Hit in the arm of the youth from Epir-/Looking in this tumult for compassion./This touch so full of contempt, unknown face/Of the man with an axe so much infuriated/ Trampled the dignity of the youth/That he slowly moved his hand in the man's direction/With lazy mouths he said "Viscious!"/But already when/He threw him, bent like an anchor, to the ground/ O Gods!!/The crowd started to shout "Priest's murder!"/At that moment the golden horns of the bull/Were held with a rope, and the great crowd/Had no ways to get rid of their desires./The police entered with their spears, where the son of Alexander kept under his foot/the man/And some gardener with words/soothed the angry servants/who carry ropes and incense/ Whenever sacrifices are to be made./Let him go! Shouted the centurion,/When the youth: "Make him drop the axe!" to which/The gardener added: The madman with the axe!"/And the centurion beckoned with his hand - At this moment/ The priests' servant got free - and then/The brown axe went down his hands like a bird/He cut the air with its golden wing -/Fell, Alexander's son shivered - and collapsed. 
of Pisma wybrane (Selected Works), which for the first time included the factual commentary to the whole text of Quidam, the following explanation is provided

[XXIV] 165 Bull (...) H o l - Imperial Rome knew no such cult; this detail was probably invented by Norwid, who in Hadrian's biography written by Elias Spartianus had read that the emperor had been worried by riots in Alexandria which started because of Apis. If he had added Hadrian's immense curiosity, Norwid might have arrived at the conclusion that Roman priests may have also come across their own 'Apis', which they wanted to catch and to show to Hadrian. ${ }^{16}$

Unfortunately, the Editor is wrong! Let us start with the bull (or the bullock). The point here is not some cult of the bull, but the bull as a sacrificial animal. In ancient Rome, from times immemorial, apart from bloodless sacrifices, bloody sacrifices had also been practised (as was the case in Greece). The ritual of killing created a sequence: a sacrificial animal (it could have been a sheep, a pig, a cow or a horse) was decorated with wreaths and ribbons; bulls had their horns gilded. A priest ordered deep silence (linguis favere), prayed to god, to whom the animal was to be sacrificed, cut a tuft of the animal's hair and threw it into the fire, "and then he moved a knife above the animal's back from head to tail and declared:(hostia) macta est-(the animal) is dead." Then it was killed with a club; this was performed by a victimarius if it was bigger, a cultrarius, if it was smaller. The priest cut the throat, collected the blood in a vessel, sprinkled the altar with it, and finally stripped off the animal's skin. A fortune teller (haruspex) carefully examined the animal's heart, liver and lungs. ${ }^{17}$ Later, incense was spread over the altar, part of the meat was burnt, while most of it was ordained for a feast which soon began.

\footnotetext{
16 J. W. Gomulicki, Objaśnienia, in C. Norwid, Pisma wybrane, vol. 2: Poematy, 1985,430 .

17 O. Jurewicz, L. Winniczuk, Starożytni Grecy i Rzymianie w życiu prywatnym i państwowym, Warszawa 1973, 198-199.
} 
The issue of the cult itself is quite separate. The case here does not concern-as Gomulicki suggested in a not very clear way-Apis. It would be really strange if in the key scene of his long poem, so strongly grounded in historical realities, Norwid suddenly decided to 'invent details'. Anyway, the research of historians on the religion and history of the Roman Empire in the area of assimilations of eastern cults indicates different tendencies than the ones described by Gomulicki. It is true that in ancient Rome in the times of the Empire elements of many eastern cults (for example the cult of Isis) were assimilated, but during Hadrian's reign this trend was reversed. Tadeusz Zieliński-a well-known expert in these issues-suggested that in this period a renaissance of the traditional Olympian gods took place, and the eastern cults were in decline. Zieliński, while describing the development of different cults in Roman legions, noted:

The set of his gods can be seen on altars which were consecrated in the times of Hadrian. It looks as follows: Iovi Optimo Maximo, Iunoni, Monervae, Marti, Victoriae, Herculi, Fortunae, Mercurio, Saluti, Felicitati, Fatis, Campestirbus, Silvano, Apollini, Dianae, Eponae, Sulevis et Genio singularium. Please note: not a single eastern deity! Most of them are the ancient Olympian gods with added personifications which evolved out of them in the manner characteristic for Roman religion. Apart from them we have some deities of local cults, mostly Gaelic, which were probably indigenous for soldiers of a given legion. But no eastern deities. During the reign of Hadrian! Who himself was a tireless wanderer and simultaneously a reformer of the Roman army, and he could have easily added to this religion these deities with which he got acquainted during his travels. He would visit Phrygia in Asia Minor and must have been acquainted with the ecstatic service of Kybele with Atis, but he did not let them enter his army. ${ }^{18}$

It is the cult of Hercules which is particularly important for our considerations. In ancient Rome it was one of the oldest of cults. It was 'nationalized' in 312 B.C., that it is at the moment in which the post

18 T. Zieliński, Religia cesarstwa rzymskiego, Toruń 2000, 108-109. 
of the censor was held by Appius Claudius Caecus, a famous reformer who built Via Appia and Aqua Appia, the first aqueduct in the Eternal City. Hercules was worshipped under the names of Victor (winner) and Invictus (invincible). The cult of Hercules was popular both in the republican and imperial periods. He was a patron of many military commanders and politicians, and later of rulers. For example, Marc Anthony at the end of his life wanted to be perceived as the 'New Hercules', while Trajan regarded Hercules as one of his guardians. Commodus was probably the boldest of them all. He deified himself when still alive, regarding himself as the incarnation of Hercules. As Hercules Romanus he appeared wearing a lion's hide and with a club in hand-the traditional outfit of a hero. The imperial Antonine dynasty chose Hercules as its patron, and Hadrian, after all, was one of them. During the reign of Antonine the axiology of the cult changed. This was the period when stoics popularized the idea of a good ruler, who while sacrificing himself for the good of his 'patria' and its inhabitants, at the same time reigned with power which was strong, but also wise and just. Hercules was regarded as a model of a monarch-who at the same time was an ordinary and good man. He became a symbol of hard work, moral virtues, and his famous twelve labours became a symbol of the fight between good and evil. A strongman of yesteryear, a patron of great triumphant military commanders and aristocracy, was slowly turning into a deity popular with populace.

The first and most important place of his cult in Rome was Ara Maxima, located at Forum Boarium, the place where, as we remember, the protagonist of Norwid's long poem dies. The bull which appears in Quidam in the Market Square is therefore closely connected with the cult of the ancient hero: the animal was probably destined for a bloody sacrifice in the name of Hercules. ${ }^{19}$ According to the legend,

\footnotetext{
19 See S. B. Planter, Th. Ashby, A Topographical Dictionary of Ancient Rome, Oxford 1929, 254. See also E. Nash, Bieldllexikon zur Topogra-phie des antiken Roms, v. 1, Tubingen 1962. For information on Forum Boarium and Ara Maxima see also: F. Castagnoli, Topografia di Roma antica, Torino 1980; F. Coarelli, Rome. Ein
} 
Ara Maxima was built by Evander, and the first sacrifice in honour of his own father (Zeus-Jupiter) was to be performed by Hercules himself. From the very beginning and for many centuries members of two families, Poticisus and Pinariuses, performed the duties of priests there. ${ }^{20}$ Virgil, in the eighth book of the Aeneid, wrote in this manner about this very altar and Hercules-saviour himself, who took cattle away from Caucus, a demon of darkness and the underworld:

Odtąd cześć dajem zbawcy, w potomnych pamięci

Radosny dzień ten. Potyt nasz pierwszy go święci

I Pinariów ród, starzy Alcyda wieszczkowie.

On w gaju wzniósł ten ołtarz, co wielkim się zowie,

I wielkim go na zawsze kraj będzie zwać cały. ${ }^{21}$

Admittedly, Dionysus remarks that the altar itself was not very grand, but we are not concerned with grandeur here, ${ }^{22}$ but with the close connection of Ara Maxima with the whole set of foundational myths connected with the Eternal City.

Games were organized in Rome in honour of Hercules, and sacrifices were made in the Greek manner. Once a year a praetor with an uncovered head and a wreath made of poplar leaves at the great altar, Ara Maxima in Forum Boarium, made a sacrifice of a young bull, which had not tasted a yoke. Then he performed a libation (a special sacrifice of pouring liquid into the ground) with wine from a wooden chalice soaked in tar, which according to the myth, Hercules had used in Italy. ${ }^{23}$

archaologischer Fuhrer, Mainz 2000; L. Cur-tius, A. Nawrath, Das antike Rom, Wien, Munchen 1963; and : R. R. Dudley, Urbs Roma. A Source Book of Classical on the City and its Monuments, London 1967 and L. Richardson, A New Topographical Dictionary of Ancient Rome, Baltimore, London 1992.

20 See M. Grant, Mity rzymskie, transl. by Z. Kubiak, Warszawa 1993, 75-76.

21 BRAK PRZYPISU!

22 See L. Crassus, Tańczący z ciołkami, czyli kult Herkulesa w Rzymie, in www. hi- storica.pl

${ }^{23}$ On the cult of Hercules and sacrifices of praetors T. Zieliński, Religia cesarstwa rzymskiego, op. cit., s 116-117. On this cult in Rome see Ibid, 116-125. 
Apart from the place, situation and circumstances of the Epirian's death at the Market Square, there is one more detail worth explanation; a detail which, similarly to the ones mentioned, takes on a metaphorical meaning (according to some researchers it is the case of parabolic meaning). Obviously, I have in mind not the time of the events in the depicted world but historical time which was fixed in this text in the shape of allusions and different tropes. An attempt to reconstruct this historical time in Quidam was first made by Władysław Dobrowolski:

Bar-Kochba at least a few months before going to Palestine must have met Quidam, that is in the spring, as we may deduce from the mention of the blooming lilies and sharp morning chill of the year 131 A.D. From the time of Quidam's arrival "a year passed and many hours"-which means that Quidam arrived in Rome in the year 130. The poem ends on 28 April 133 or 134, the date of 28 April is imposed by the mention that Lucius is going to Flora races and, as it is known, Flora's festivities started on 28 April. ${ }^{24}$

The border date-the year 133-is explained in this way:

[...] the rising started in 131 [...] and it was only after the final defeat of Tinnius Rufus in 133 that Hadrian sent many legions, with Publius Marcellus and Lolius Urbicus as commanders. Only after the defeat of both of them, so it was only around the year 139, the news about it might have been circling in Rome. So Jason received the first news about the victory in Judea almost two years after the beginning of the rising, almost at the end of its success phase. Further, in part XXIV we read "a rebellion in a distant province, not taken seriously even by the emperor". So in order to quell this rebellion Hadrian, already in the year 134, fetched legions from Phoenicia, Arabia, Moesia, Mauritania, and the commander Lolius Urbicus from Lower Germania. $^{25}$

24 Wt. Dobrowolski, Norwida opowieść o wiecznym Rzymie i wiecznym człowieku "Quidamie”, „Pamiętnik Literacki” 1927 (XXIV), 299.

${ }^{25}$ Ibidem. 
Zbigniew Zaniewicki, in his 1939 Ph.D. Dissertation, corrected these findings:

Dobrowolski is convinced that in the poem the meeting of the Epirian with Bar-Kochba happened in the spring of 131. We are certain that the plot of canto II is set exactly during Flora festivities (28 April-3 May) 132 A.D., and the final canto of the poem, according to Dobrowolski: "During Flora holidays in 133 or 134 A.D."according to us, in the time of Pascha (the first week of April) in 133 A.D. "The equestrian races" to which Pomponius is going do not necessarily have to be races during Flora holidays: they may just be preparations for these holidays, while the day of Pascha is clearly marked. In this way these events happen exactly a hundred years after "the last supper" and the arrest of Christ, of which the false reflection is the supper and Jason's arrest. ${ }^{26}$

This last remark about the holiday of Pesach is extremely important for the interpretation of canto XXIV. The plot of the last part of the poem (cantos XXII-XXVII) takes place within a few hours of one day. The events in the Market Square in Jason's house take place simultaneously (this is a type of scenic device which Norwid eagerly used in this poem). It could be stated that from the perspective of the Magus and his circle-this is the time of the holiday of Pesach (although washing the feet of a disciple by the Master brings unambiguous Evangelical associations), while from the perspective of the Gardener-this is the time of Good Friday. It is in this context that he interprets the death of Alexander's son.

The pieces of information about Forum Boarium, bull sacrifices and the cult of Hercules, the time of events (the holiday of PesachGood Friday) given here in a brief summary create the symbolic and metaphorical surrounding and background for the death scene of the Epirian in Quidam. Of course, canto XXIV could be understood in general terms without deciphering this cultural context, because historical and topographical details are not inserted to build the sense

26 Z. Zaniewicki, Rzecz o „Quidam” Cypriana Norwida, Lublin-Rzym 2007, 42-43. 
of probability or verisimilitude of the text, or its author. As we can see, for example from this analysis, these details are not given in a direct way, exclusively with radical verisimilitude (although Norwid does not avoid them), with attention paid to details, with the intention of the exactness of photography (or rather of daguerreotype). Norwid here tended to use sketches, his favourite 'close-ups' and allusions. He left tropes and traces all over the text and, in a way, forced his readers to identify and also to interpret them. At the same time he did not curb his predilection for accumulating - at times quite artificialdetails. They make the semantic structure of the text denser (raising analytical curiosity at the same time). However, they do not always keep up with the quality and value of poetry itself. Norwid was moving on a flexible and narrow line, trying all the time to keep a balance between the structure and the general sense. The deep net of details of topographical, situational and historical details introduced into the text of Quidam, in a way, reaches its climax in canto XXIV, which we are dealing with here. Each of these details becomes a sign, but what is more, they are all subjected to the rule of the semiotic complementarity of the world. This could be compared with some semiotic maps in which each individual element, taken separately, is a sign of a certain fragment of reality, but at the same time the full sense of this element is revealed only in the contexts of other elementssigns, which in turn allow us to understand the fullness of reality, to construct its complete 'virtual' picture. Norwid's realism is neither concerned with ultra-realistic accurateness towards the material structure of the world, nor with the accurateness and 'congruency' of verbum towards res (although in the case of Quidam this is also the case), but is concerned with the hidden sense of reality, with metaphysical qualities and values which stand behind details, facts and events. Diverse details deeply anchored in the real world were used by Norwid to reveal a larger plan of meanings. ${ }^{27}$

27 These are obviously not new ideas for Norwid scholars. See, for example, I. Stawińska, O prozie epickiej Norwida. Z zagadnień warsztatu poety dramaturga, in Eadem, Reżyserska ręka Norwida, Kraków 1971, 281-292; S. Sawicki, Norwida walka 
What happens in the Market Square is, on the level of reality, only a little-as Norwid himself described-'accidental' fact; in its essence-despite suffering and tragedy-of little meaning, even in the perspective of dimensions of the world of the text. But at the same time the Epirian's death is subjected to the famous Norwid's rule of metaphorical generalizations. We are convinced about it by the speech of the Gardener over the body of the son of Alexander; this is a symbolic exegesis of this death:

Ogrodnik tylko, obecny w tej sprawie,

Wyciągnął rękę i rzekł: „Błogosławię

Duszy twej-a wy! co z n a c z y skonanie

Młodzieńca tego, kiedyś się dowiecie -

Którzy jesteście ślepi Kainanie,

Rozbijający braterstwo na świecie,

Obrazy stawiąc własnego zbłąkania

Czynami, z których każdy was o d sła n i a -

I jako scena w teatrum naucza,

Do prawd zakrytych by szukano klucza -

Bóg, gdy ofiarę nożem czynić miano

Na niewinnego młodzianka wzniesionym,

Nasunął owcę w ciernie uwikłaną,

Krwią ludzką, nie chcąc, aby był chwalonym;

I wolał przenieść ofiarne skonanie

Nad krwi wylanie - -

Ale wy - byka minąwszy toporem,

W człowieczej krwi się chłodzicie - szaleni!

Tym, mówię, czytać gdy poczniecie wzorem

Pisanie, co się w powietrzu czerwieni,

Padniecie na twarz -"

$$
(\text { III, 212) })^{28}
$$

z forma, Warszawa 1986, 119; S. Rzepczyński, Wokót nowel „włoskich " Norwida, Słupsk 1996, 62-82.

${ }_{28}$ The Gardener only, present in this case./Outstretched his hand and said "I bless/ Your soul and you! The meaning of the death/ of this youth will know one day -/ You who are blind sons of Cain,/Destroying brotherhood in the world,/Praising your own madness/With deeds, every one of which, exposes you-/And shows as 
The deeper sense of the death of Quidam could be read in the context of Christ's Passion (also recalling the biblical situation of Abraham, who made the sacrifice of Isaac); it is not only the protagonist's death itself but also a long line of details which allows such an interpretation. In this interpretation a multi-layered sense is revealed; also the sense and picture of their mutual connections and relationships. It is not only the fact of the death itself which has metaphorical meaning, but also its circumstances. Circumstances connected, first of all, with the place. Forum Boarium was the heart of ancient Rome, one of its primary sources, genius loci forgotten by great history. But the situation in which the main protagonist found himself also became metaphorical: according to the Gardener, he followed in the footsteps of Christ. He returned at a very specific moment in time and became a kind of 'memento' of Good Friday. Even such elements as a sacrificial bull or Hercules (god-man) - the cult of whom although absent from the depicted world could be sensed in the deep structure-find their positive equivalents in the Christian passio.

Introducing generalizations built out of details and small concretes in canto XXIV not only focuses our attention and sensitivity on the event itself-on the death of the Epirian, which undergoes the process of becoming metaphorical in Christian terms. Perhaps a basic generalization becomes even more important; the generalization which was signalled by Norwid in the introduction to the text, in "List do Z.K.," (“A Letter to Z.K.”) where, among other issues, historical and civilizational ones, are discussed:

Civilization, most probably, is similar to this church which you have seen so many times behind the Capitoline Hill in

a scene in the theatre/To look for keys to hidden truths-/God, when the sacrifice with a knife was to be made/Directed at the innocent youth/Pushed a sheep entangled in thorns,/Did not want to be praised in human blood./And preferred to move the dying of the victim/Over spilling of blood-/But you, having the bull just missed with your axe,/ Are cooling off in man's blood-O madmen!/I speak to you, when you start reading/The writing which is reddening in the air,/You will prostrate yourselves! 
moonlight-to the church, which in the square of columns of an ancient temple, as a dove in a broken cave, stays on, so, when you walk to attend the Christian mass, you cross there an antechamber of Jove. [...]. Civilization consists of accumulated knowledge, JewishGreek-Roman, and its womb is Christian. Do you think that it is now triumphantly shining in reality, conscious of itself? (III, 80)

The Epirian's death in relation to these greater meanings was considered by Arent van Nieukerken:

We have a troubling problem here. In the whole of Rome no one, apart from the Gardener (not excluding the victim himself: "And he said: 'To die-on the market-like at home/To die-irony laughs at itself") understood the true sense of Alexander's son's death, with whom Norwid was identifying himself. The author (and "we" readers) on the metaphysical level (the perspective of Gwidon, the gardener) therefore knows more than (the son of Alexander) experiences on the existential level. So, is it not possible to create a 'non-personal' world depicted in which the tension between a 'knowing' author and an 'experiencing' protagonist disappears, to create into life (of course in the literary sense) a world which at first glance is devoid of all references to sacrum, while when we look closer we discover that in the space numerous signs of 'holy history' were encoded? Such an existential symbolism is the foundation of poetics of the short, epigrammatic texts Vade-mecum consists of. In these texts the author and the audience both equally retreat, through excluding themselves from the depicted world. Because the situation of recognizing sainthood is not presented as an individual experience of one man, with which 'I' identifies himself hic et nunce, but is presented as a line of an individual situation in which the subject is always "someone -some man-quidam". ${ }^{29}$

I do not really know the nature of the "troubling problem" of Arent van Nieukreken. What I know is that the levels of epistemological possibilities defined and described by him, which

29 A. van Nieukerken, Osobowość a anonimowość w „przypowieści” o „rzymskim bruku”, „Teksty Drugie” 20oó, no. 5, 147. 
were to reveal the complicated world of the poem and relations between the protagonists, the narrator and the author, in fact tend to simplifications. I agree that the son of Alexander experiences everything on the existential level, although even in this area there exist tropes which force a slightly more cautious approach; I have in mind, most of all, some of the fragments of the protagonist's 'diary', the Epirian's stance during the process of three Christians in front of Jove's temple, and also his final words; the words about irony. Are they not a call for or the premonition of the 'truth'? Particularly if we remember Norwid's treatment of irony in canto XI of Rzeczo wolności słowa (On Freedom of Speech). The claim that the metaphysical level ("the point of view of Gwidon the gardener"-as van Nieukreken put it) changes and deepens the sense of the first level. However, it is difficult to agree with the identification of the author with the son of Alexander. ${ }^{30}$ It is true that the narrator-author tries to be close to his protagonist and often even takes his point of view, is emphatic to his sufferings and experiences. Anyway, he treats Gwidon in a similar way, so when Gwidon discovers the deeper meaning of the Epirian's death we do not have doubts about the 'position' of the author; but this does not mean identification. History is the obstacle. The author is looking at the events from the perspective of the nineteenth century, and he stresses it strongly in the fragment from the introduction: asking the 'addressee' a rhetorical question about the state of contemporary Christianity: "do you think that [Christianity] in reality conscious of itself, has already triumphantly shone forth?” (III, 80). This is the cause of the closeness to the protagonist and the gardener's exegesis, but also of stressing his own perspective, which is, obviously, much wider. Apart from the existential and metaphysical we have here one more level: that of history-philosophy. And this level is the author's 'domain'. When we read closely the words of the Gardener over the body of the son of Alexander, we see a lack of straight

${ }^{30}$ I disregard here completely the issue of identifying of a reader with the author, of which Nieukerken writes- because this issue is not-in my opinion-as obvious and simple as he supposed. 
analogies or even allusions which would refer to Christ (although the sense of the presence of the Saviour does not leave a reader of this poem even for a moment). What is more, when the biblical story of Abraham and Isaac is recalled, and particularly when he adds in an accusatory tone: "But you-the bull having just missed with your axe/A re cooling off in man's blood—o madmen!” (III, 212)—one might get the impression that the sense of the death of the main character revealed by the Gardener does not reflect an objective truth, even if we were to take into account the perspective of hidden signs of history. Because, after all, the Epirian was not killed instead of the bull. And although in ancient Rome, even in imperial times, bloody sacrifices of men were still occasionally performed, Norwid's text did not avoid this context. Of course, the Gardener's words may be treated as a kind of a reproach to pagan Rome and its bloody rites and rituals. But the fragment in which the apocalyptic vision and the perspective of eschatology appear:

Tym, mówię, czytać gdy poczniecie wzorem

Pisanie, co się w powietrzu czerwieni,

Padniecie na twarz -

$(\text { III, 212) })^{31}$

sends us to the situation and sensitivity of Christians of the first centuries, when all persecutions were read from the perspective of the fast approaching end of times. It is worth noting herefollowing Tadeusz Zieliński-that together with "the reign of Hadrian and the first half of the 'period of glory' of the Roman Empire, in the year around 140 A.D., there ended a period which we refer to as primal Christianity (Urchństentum)". Christians lived then "expecting the second coming of Christ for the Last Judgement, and thus they expected a near end of the temporal world and considered their own existence as provisional." 32

\footnotetext{
31 I speak to you, when you start reading/The writing which is reddening in the air,/ You will prostrate yourselves!

32 T. Zieliński, Chrześcijaństwo antyczne, Toruń 1999, 195.
} 
The metaphysical level of reality, which the Gardener reveals, is therefore, in an objective sense, independent of history, present in each period, although the very person and the way in which he presents the events and the world is deeply embedded in the specific time of history and in the specific space-the space of ancient Rome. He himself is one of these unusual signs of 'holy history', seemingly invisible in the world of difficult existential experiences, marked with the darkness of suffering, even of death, subdued by external 'shape'. Thanks to him an unusual perspective in this poem opens up, when every man faced with the huge universe is lonely and anonymous, and simultaneously becomes 'someone' in the face of individuals similar to him. Almost everything, including elements of the real world, undergo such a change in Quidam. Hence, the motif of a stone similar to agate with which canto XXIV ends, which at first was to be used to manufacture butchers' scales and later became the symbol of Christian martyrdom:

Na bruku, który właśnie opuszczano,

Podobnym, $\mathrm{z}$ barwy, miejsca i wspomnienia,

Do w a g - r z e ź n i c z y c h - te, z urządzeń zmianą,

$\mathrm{Z}$ ciężkiego nader że były kamienia,

Do nóg męczeńskich gdy przywiązywano,

Krwi nieraz świętej bywał na nich napis,

Stąd kamień wag tych zwą: martyrum-lapis

* Kamień podobny do agatu jasno-zielonego, z którego wagi robiono, a potem, zmieniwszy je, zużywano ten ciężar w męczeństwach, rozmaicie go stosując; pierwej zwany przeto aequi-pondus, potem zaś la-pis-martyrum.

$$
(\text { III, } 214)^{33}
$$

\footnotetext{
33 On the cobblestones, which were just being deserted,/Which was similar in colour, place and memory/To butchers' scales, these/Were made of heavy stones,/ When they were tied to the legs of martyrs/Sometimes they bore inscription in saints' blood/That is why this scale-stone is often called martyrum-lapis ${ }^{*}$. ${ }^{*}$ A stone similar to light green agate, out of which scales were made, and later, having changed them, these weights were used in martyrdoms, using it in different ways, thus first it was called aequi-pondus, and later lapis-martyrum.
} 
The sense of history in terms of philosophy in which man-quidam is immersed-Everyman and Someone in one-is recognized from the point of view of the author-narrator, who reads the signs of 'holy history' in a way which goes beyond the horizon of the metaphysical sensitivity of the Gardener, and even more beyond the level of the existential experience of the Epirian. We could speak here about a specific paradox if we take into consideration the fact of the limited competence of the narrator in the world depicted in this poem; of his knowledge which is often limited to radical realism locked within cognitive capabilities. ${ }^{34}$

Primarily, from the point of view of the author-it is strongest in "Letter to Z.K.", although traces of his presence are also visible in other fragments (generalizations and other fragments removed from concrete time and space, removed from the 'material world' depicted in the text) -Christianity transcends the boundaries of time. Here the death of the Epirian is not only some harbinger of the fulfilment of history, as the death of each man-quidam in the period 'after Christ', but also the testimony of the constant presence of Christ in history. Everything which announces the coming of the Saviour and what must (no matter whether one wants it or not) come closer to it, enters into certain relationship, becomes a kind of indelible sign. In this context the encoded signs of 'holy history', present in places, rituals, gestures, situations, events, even such which have little in common with the Christian way of experiencing history (indeed, being an important contradiction to this experience, like in pagan Rome) in its deepest and most important sense, bring the perspective of the Resurrection and the Passion closer. In Quidam Christianity becomes not only a historical and cultural formation, which appeared

\footnotetext{
34 The role of description and imagery (basic categories of Quidam) many researchers have written on: : Z. Łapiński, Obrazowanie w,Quidamie”, „Roczniki Humanistyczne” v. VI (1956-1957) (1): „Prace o Norwidzie”, . 117-173; Idem, „Gdy myśl łączy się z przestrzenia”. (Uwagi o przypowieści „Quidam”), „Roczniki Humanistyczne” 1976 (1) . 225-231 and A. Cedro, Przypowieść, historia. O kierunkach lektury „Quidama”, „Studia Norwidiana 7 (1989), particularly 96-103.
} 
in the history of the world at the moment when Christ appeared, but the 'womb of civilization'; that is Timeless value and destiny of history. 